\title{
BUSINESS PERFORMANCE OF 15 LARGEST EXPORTERS IN FOOD-PROCESSING INDUSTRY IN THE PERIOD 2008-2014
}

\author{
Zoran Jeremićn , Marko Milojević2 ${ }^{2}$ Ivica Terzic ${ }^{3}$
}

\begin{abstract}
Summary
Agricultural export in Serbia is dominated by primary agricultural products with highly processed products having only 20\% share in total exports. Low share of the processed agricultural products in total exports provides an opportunity to increase export and change its structure towards higher value-added products. In order for it to happen, the food-processing industry focused on processing domestic agricultural products needs further development. In this paper, we have analysed business performance of 15 largest exporters in the food-processing industry with the aim to get insight into their export competitiveness. The paper concludes that these companies are large net exporters that provide high added value to the country's economy. However, business performance of the exporters under analysis are not satisfactory and their export competitiveness needs the improving. According to projections, the upcoming period will bring the most difficult challenges for the sugar-producing companies while the fruit-processing sector has the best long-term potential for export growth.
\end{abstract}

Key words: food-processing industry, export, competitiveness

JEL: $G 32, Q 14$

\section{Introduction}

After a minor setback in 2009, Serbian export continued to increase, recording a slight changeof its structure towards higher share of processed and higher-value products. In this respect, we may observe that export is one of rare bright sides in this country's

1 Zoran B. Jeremić, Ph.D., Full Professor, Singidunum University, Faculty of Business Belgrade, Danijelova Street no. 32, 11000 Belgrade, Serbia, Phone:+381 113020035 , E-mail: zjeremic@singidunum.ac.rs

2 Marko Milojević, Ph.D., assistant professor, Singidunum University, Faculty of Business Belgrade, Danijelova Street no. 32, 11000 Belgrade, Serbia, Phone:+381 62282777 , E-mail: mmilojevic@singidunum.ac.rs

3 Ivica Terzić, Ph.D., assistant professor, Singidunum University, Faculty of Business Belgrade, Danijelova Street no. 32, Belgrade, Serbia, Phone:+381 113020035 E-mail: iterzic@singidunum.ac.rs

EP 2016 (63) 3 (943-957) 
economy but nevertheless, thischange is rather negligible compared to the export level which would be able to turn the negative economic trends into positive. (Milojević, Terzić, 2015). The areas in which Serbia has a chance for significant improvement are primarily food-processing industry, car and car parts industry, electrical appliances industry and informatics. The agriculture is the single most underutilized resource since primary agricultural products are still predominant in export structure (Pejanović, 2009). Therefore, it is vitally important to develop a strong food-processing industry which relies on domestic agricultural raw materials. About the problems of agriculture financing, measures to overcome the economic crisis, wrote most prominent authors in the field of agriculture (Pejanović et al., 2009; Jolović et al., 2014). They concluded that the state provides incentives but that in times of economic crisis they are inadequate.A certain improvement has been achieved, as noted by the World Bank: "Serbia is in a good position in food-processing; its exports of such goods have grown at least as much as those of Bulgaria, Croatia, Romania, and Slovakia, though not as much as those of Hungary or the Czech Republic" (World Bank, 2012).

In respect of export, the food-processing industry has several potential advantages over other industries (Miletić at al 2012; Ljunović et al, 2015). Its growth potential is enormous since similar-sized countries have multiple times higher exports than Serbia. As opposed to industries which rely heavily on imported components (like largest exporters: Fiat and Zelezara), the use of imported products is relatively low in the food-processing industry. Therefore, the food-processing companies should also be large net exporters which would be very important for the country's balance of trade and balance of payment (Simeunović, Milošević 2013). Also, there is the issue of often minimum higher value added to the products manufactured by large food exporters (Stevanović at al, 2013). Therefore, this paper aims to test these hypotheses regarding the significance of food-processing industry by analysing business performance of 15 largest exporters from this industry in the period 2008-2014, which also made it into top 100 largest exporters in 2014. When it comes to export competitiveness, numerous researches have shown that, in today's globalized world, large companies more easily enter an export market which is characterized by the strong competition. It is easier for large companies to recruit personnel, to develop and ensure standardization of the products and obtain necessary certificates which are a precondition for entering foreign markets. Therefore, 15 largest exporters can also be a representative sample for analysis of export performance and competitiveness of this entire sector. One should bear in mind that those 15 companies which are classified as large companies in Serbia would fall in the category of small or mid-size companies in the global market. On the other hand, food-processing companies classified as small and mid-sized companies are not competitive in export and make only $4.3 \%$ of exporters in total. These companies operate in low technology areas, making products of small added value and diversity which results in poor market position, low prices and income margins (Strategy for development of small and mid-sized companies, entrepreneurship and competitiveness in the period 2015-2020). 


\section{Methodology}

This paper analyzes business performance of 15 companies from the sectors of food processing industries which by their exports belong to the 100 largest exporters in the Republic of Serbia. Data on exports has been collected from Customs Administration and the data on business operations from the website of the Agency for Business Registers. Out of 100 largest exporters 15 of them belong to the the processing industry and they are classified as large companies.

The methods that were used in the scientific paper are description, comparison, analysis and synthesis. In order to answer on the question of research Du Pont formula was applied. Du Pont formula explains how the effect of profitability, leverage and turnaround assets speed affect on the company's business operations.

\section{What companies are largest exporters in food-processing industry?}

Large exporters, namely, have better chances of conquering a foreign market and may significantly contribute to the integration of small producers involved in the making of the final product intended for export. For this reason, we examined 15 exporters in the food-processing industry that are also among the top 100 largest exporters. The aim of this paper is to analyse their business performances based on their operating results in the period 2008-2014 in order to determine their growth potential in regard to export depending on the agricultural products they process. Table 1 displays 15 foodprocessing exporting companies which ranked among top 100 exporters in Serbia in 2014 based on export achieved. 
Table 1. Fifteen Largest Exporters in the Agricultural Products Processing Industry (in Millions of Euro)

\begin{tabular}{|c|c|c|c|c|c|c|c|c|c|c|c|c|c|c|c|c|c|c|c|c|c|c|}
\hline & Company name & 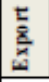 & 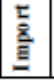 & z & $\frac{5}{\frac{2}{2}}$ & 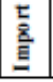 & $z$ & $\begin{array}{l}\mathrm{T} \\
\text { o. } \\
\text { d. } \\
\end{array}$ & $\begin{array}{l}\text { 들 } \\
\text { 商 }\end{array}$ & $\bar{z}$ & 동 & $\begin{array}{l}\frac{5}{2} \\
\text { 啇 } \\
\end{array}$ & ż & \begin{tabular}{|c}
$\mathrm{t}$ \\
$\frac{\mathrm{a}}{2}$ \\
$\mathrm{i}$ \\
\end{tabular} & 突 & ż & $\begin{array}{l}\mathrm{T} \\
\frac{\mathrm{z}}{\mathrm{\alpha}} \\
\mathrm{B}\end{array}$ & 동 & 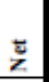 & $\begin{array}{l}\mathrm{r} \\
\frac{2}{\alpha} \\
\frac{\mathrm{d}}{\mathrm{a}}\end{array}$ & 들 & ż \\
\hline & & \multicolumn{3}{|c|}{2014} & \multicolumn{3}{|c|}{2013} & \multicolumn{3}{|c|}{2012} & \multicolumn{3}{|c|}{2011} & \multicolumn{3}{|c|}{2010} & \multicolumn{3}{|c|}{2009} & \multicolumn{3}{|c|}{2008} \\
\hline 23 & $\begin{array}{l}\text { SOJA.PROTEIN } \\
\text { Bečej } \\
\end{array}$ & 64 & 2 & 61 & 63 & 3 & 0 & 57 & 2 & 55 & 45 & 17 & 27 & 30 & 6 & 24 & 17 & 6 & 12 & 16 & 1 & 15 \\
\hline 26 & V.OIL, Šid & 52 & 3 & 49 & 72 & 3 & 0 & 81 & 12 & 69 & 74 & 10 & 64 & 66 & 9 & 56 & 42 & 9 & 32 & 51 & 2 & 49 \\
\hline 27 & $\begin{array}{l}\text { SUNOKO,N. } \\
\text { Sad }\end{array}$ & 50 & 8 & 42 & 76 & 15 & 0 & 69 & 7 & 62 & 59 & 10 & 49 & 86 & 3 & 83 & 44 & 2 & 42 & 48 & 2 & 46 \\
\hline 36 & $\begin{array}{l}\text { SWISSLION, } \\
\text { BEOGRAD }\end{array}$ & 38 & 47 & -9 & 32 & 39 & -2 & 34 & 21 & 12 & 15 & 6 & 9 & 0 & 1 & 0 & 20 & 13 & 7 & 6 & 2 & 4 \\
\hline 42 & $\begin{array}{l}\text { DIJAMANT, } \\
\text { Zrenjanin }\end{array}$ & 35 & 23 & 12 & 30 & 16 & 13 & 31 & 13 & 17 & 21 & 13 & 8 & 21 & 12 & 9 & 23 & 16 & 7 & 24 & 19 & 5 \\
\hline 46 & IE-TO, Senta & 33 & 3 & 30 & 25 & 3 & 22 & 32 & 2 & 30 & 27 & 3 & 24 & 23 & 3 & 21 & 26 & 0 & 26 & 20 & 2 & 18 \\
\hline 64 & $\begin{array}{l}\text { KONZUL N. } \\
\text { Sad }\end{array}$ & 23 & 14 & 9 & 20 & 12 & 8 & 25 & 12 & 13 & 19 & 13 & 6 & 11 & 3 & 8 & 7 & 2 & 5 & 5 & 12 & -7 \\
\hline 68 & $\begin{array}{l}\text { RAUCH } \\
\text { SERBIA }\end{array}$ & 22 & 11 & 11 & 17 & 8 & 9 & 18 & 15 & 4 & 12 & 8 & 3 & 9 & 9 & 0 & 7 & 8 & -1 & 6 & 10 & -3 \\
\hline 70 & $\begin{array}{l}\text { NECTAR B. } \\
\text { Palanka }\end{array}$ & 22 & 19 & 4 & 21 & 11 & 11 & 22 & 13 & 9 & 23 & 10 & 14 & 19 & 8 & 10 & 14 & 6 & 8 & 15 & 10 & 5 \\
\hline 71 & $\begin{array}{l}\text { SEECERANA } \\
\text { CRVENKA }\end{array}$ & 22 & 1 & 20 & 28 & 2 & 26 & 24 & 6 & 18 & 28 & 2 & 25 & 22 & 3 & 19 & 20 & 1 & 19 & 23 & 2 & 21 \\
\hline 84 & MILEK Bgd & 20 & 10 & 10 & 15 & 9 & 5 & 20 & 21 & -1 & 18 & 13 & 5 & 19 & 10 & 9 & 21 & 9 & 12 & 19 & 9 & 10 \\
\hline 89 & GEBI Čantavir & 19 & 10 & 9 & 17 & 4 & 13 & 13 & 6 & 8 & 12 & 5 & 6 & 6 & 4 & 1 & 5 & 4 & 1 & 3 & 4 & -1 \\
\hline 93 & CARNEX Vibas & 18 & 5 & 12 & 11 & 6 & 5 & 10 & 3 & 8 & 10 & 5 & 5 & 11 & 3 & 7 & 11 & 1 & 11 & 13 & 1 & 12 \\
\hline 94 & $\begin{array}{l}\text { F-KA SEC. } \\
\text { Žabalj }\end{array}$ & 17 & 1 & 16 & 17 & 1 & 15 & 17 & 1 & 16 & 17 & 1 & 16 & 17 & 1 & 15 & 12 & 0 & 12 & 24 & 1 & 23 \\
\hline 97 & ELIXIR, Šabac & 17 & 1 & 16 & 13 & 1 & 12 & 6 & 1 & 5 & 0 & 0 & 0 & 1 & 0 & 1 & 0 & 0 & 0 & 0 & 0 & 0 \\
\hline & UKUPNO & 453 & 159 & 294 & 456 & 133 & 137 & 459 & 135 & 324 & 380 & 119 & 261 & 339 & 76 & 264 & 271 & 78 & 193 & 273 & 77 & 196 \\
\hline
\end{tabular}

Source: Data obtained from Customs Administration; Authors'calculations

In the group observed, majority of companies increased their export compared to 2008. This is a major success having in mind that global economic crisis had a very strong impact on Serbian economy as well. However, it may be that such circumstances forced these companies to shift their focus to export at the time when domestic market deteriorated and many companies became illiquid and insolvent, which seriously aggravated the situation in respect of collection of receivables. In such circumstances, only the exporting companies could count on more stable sources of income and survival on the market. 
Chart 1. Export and Import of Top 15 Largest Exporters in the Food-Processing Industry

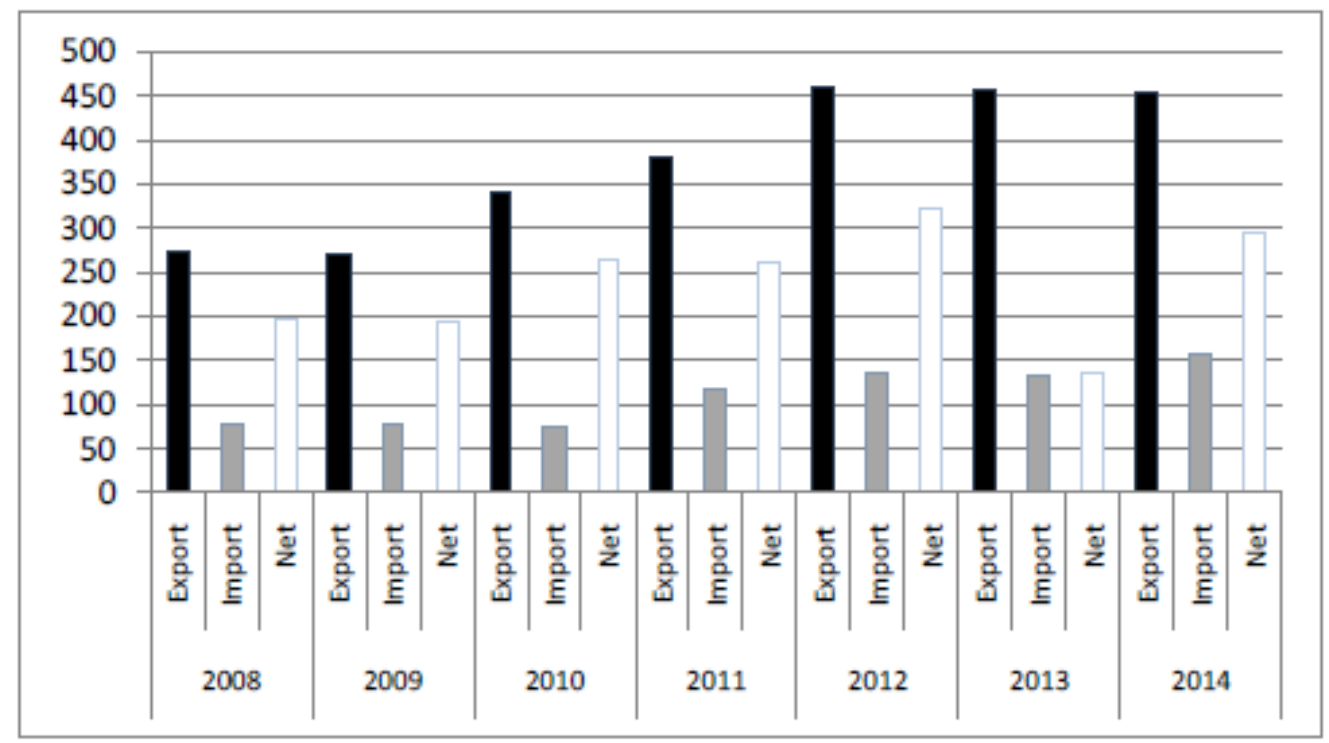

Source: Data obtained from Customs Administration; Authors'calculations

If the total export of this group is viewed in aggregate, we notice a stable growing trend up to 2012, while the same achieved level was maintained in the period afterward. Net export is constantly high, though certain decline is observed in 2014 (net export of this group in 2013 had a 71\% share in total export, and 65\% in 2014). Having in mind that Serbia's import exceeded export, that the group of 100 largest exporters had a $3.5 \%$ share in total export in 2013 and $7.4 \%$ in 2014, it is clear that 15 largest exporters have a superior position among net exporters.

Table 2. Total Net Export, NetExport of Top 100 Exporters and Net Export of Top 15 Largest Food-Processing Exporting Companies (in Millions of Euro).

\begin{tabular}{|l|r|r|}
\hline & $\mathbf{2 0 1 3}$ & \multicolumn{2}{|c|}{$\mathbf{2 0 1 4}$} \\
\hline Total Export & 13,937 & 14,451 \\
\hline Total Import & 17,782 & 18,096 \\
\hline Net Export & $\mathbf{- 3 8 4 5}$ & $\mathbf{- 3 , 6 4 5}$ \\
\hline Top 100 Export & 5,789 & 6,240 \\
\hline Top 100 Import & 5,586 & 6,701 \\
\hline Top 100 net export & 203 & -461 \\
\hline Top 100: Export share & $\mathbf{3 . 5 \%}$ & $\mathbf{- 7 . 4 \%}$ \\
\hline Top 15 food processing, export & 456 & 453 \\
\hline Top 15 food processing, import & 133 & 159 \\
\hline Top 15 food processing exporters, net & 323 & 294 \\
\hline
\end{tabular}




\begin{tabular}{|c|c|c|}
\hline & 2013 & 2014 \\
\hline Top 15 food processing, export share & $71 \%$ & $65 \%$ \\
\hline
\end{tabular}

Source: Data obtained from Customs Administration; Authors' calculations

This result is particularly important when its impact on the country's economy is taken into consideration in respect of added value products, as well as the impact it has on the large number of commodity producers whose jobs and stable income is ensured through purchase of their primary agricultural products for processing purposes.

Chart 2. Classification of Exporters in Groups per Raw Material Processed (Number of Companies, Export and Import, in Millions of Euro)

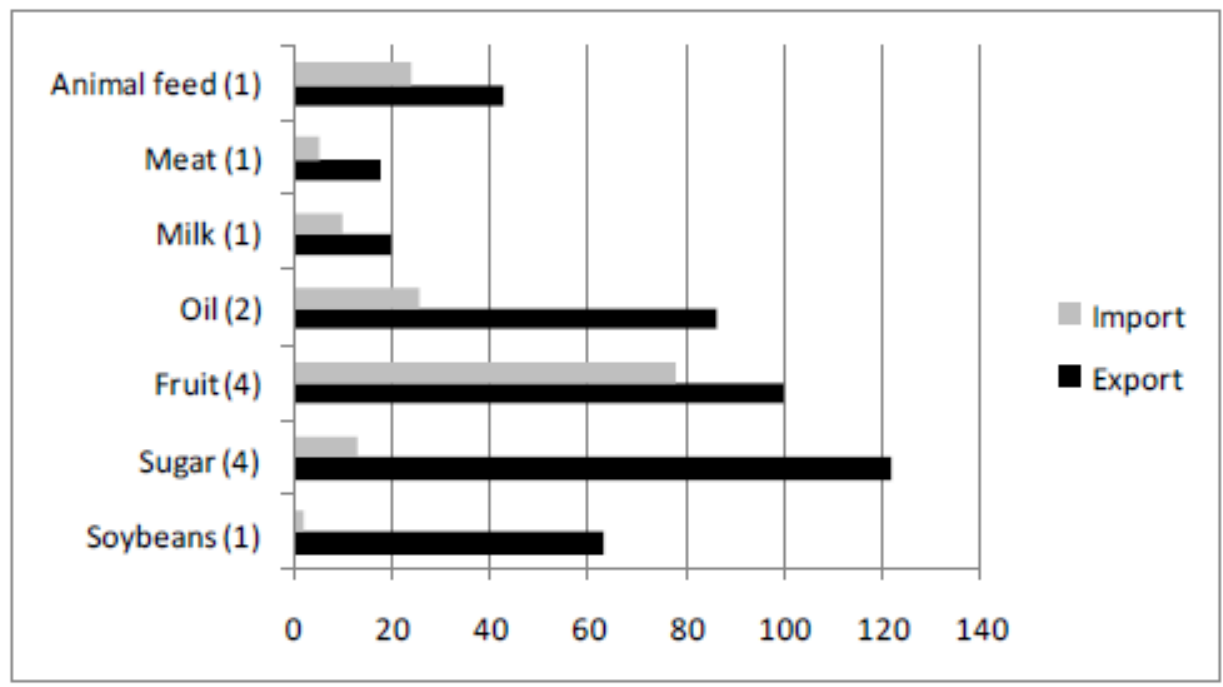

Source: Data obtained from Customs Administration; Authors'calculations

The representation of individual food processing companies according to agricultural product they process (Chart 2) indicated that the largest exporters included 4 sugar and fruit-processing companies, two vegetable oil manufacturers and two animal feed manufacturers along with three companies processing soya, milk and meat. The largest exporters were 4 sugar-producing companies'i.e. largest net exporters, which makes them all the more important ${ }^{4}$.

4 At the same time, this is identified is the greatest threat to further growth of export for this group for reasons which will be further explained in the section dealing with financial analysis of the companies' activities. The risk is increased also because significant changes are expected to occur in the sugar market due to decisions reached in the EU which will affect the competitive strength of domestic sugar-producing companies particularly from 2017 onward when the measures prescribed will take full effect. 
Soya processing companies will also experience certain risks in the future period and for several reasons. However, the analysis of this market and competitiveness of domestic products requires detailed examination. Processing of this primary material (soya) could prove an excellent example for processing of other primary agricultural products as well but also proves that associated risks in the area of business are difficult to avoid in current unfavourable circumstances in terms of business activity, financing and management.

Fruit processing is a great opportunity for Serbian food-processing companies and a potential comparative advantage to be used. However, here we also come across the issue of organization, association and enlargement of companies along with expensive financing. The fruit is mainly exported unprocessed and the quality of raw material is very good ${ }^{5}$. The food processing subsector i.e. production of juices is one with the best perspective on a global level. According to data of European Fruit Juices Association (EFJA), the production of fruit juices on a global scale reached 38.653 million litres in 2014 with about 10,000 million litres produced a year in EU alone. In Serbia, the share of fruit juices manufacturers in GDP has recorded a stable increasing trend in the last 15 years, with minimum variations. Serbia is one of the leaders in the fruit juice manufacturing industry in the region with annual production of about 230 million litres. The share which the fruit and vegetable industry has in total export varies from year to year, but its average ranges from $5 \%$ to $10 \%$, whilethe import of fruit juices is below $2 \%$. This means that net export is exceptionally high and this in itself is an enormous potential for improving the country's balance of trade and balance of payment. All the more since there is high quality raw material available and fruit processing is one of rare potential comparative advantages Serbia has in the global market.

Low share which meat- and milk-processing companies have in total exports is indicative of the poor conditions in agriculture and unused opportunities.

\section{Business performance of 15 largest exporters in the food-processing industry}

The group of 15 companies under analysis, from a cumulative perspective, recorded the growth of operating income of $34 \%$ in 2014 compared to $34 \%$ in 2008 . However, themean exchange rate of dinar depreciated against euro by approx. $36 \%$ in the same period when comparing end of 2008 to the end of 2014, and average mean exchange rate of dinar against euro (which is more relevant for comparison of income statement items) depreciated by $44 \%$. Therefore, no realistic increase in operating income was observed in the entire group. Individually though, 9 companies recorded growth even

5 According to data available at Serbia's Statistical Office, the value of fruit exported in 2012 reached 197 million euros and and 229 milion euros in 2013, and 267 million euros in 2014. According to data available at the Serbian Chamber of Commerce, the export of maize, raspberries, cigarettes, sugar and apple in the first 11 months of 2015 were among the five most significant agricultural products which generated about 800 million dollars worth of income. 
if compared in terms of euro, while 6 of those companies recorded declining operating income, 2 of which recorded lower operating income in absolute value in dinars.

Table 3. Ranking per Growth of Operating Income (in Millions of RSD)

\begin{tabular}{|c|c|c|c|c|c|c|c|c|}
\hline Company name & Assets & Capital & $\begin{array}{c}\text { Operating } \\
\text { Income }\end{array}$ & $\begin{array}{c}\text { Operating } \\
\text { Profit }\end{array}$ & Net profit & $\begin{array}{l}\text { No. of } \\
\text { employ. }\end{array}$ & $\begin{array}{l}\text { Growt of } \\
\text { empl. }\end{array}$ & $\begin{array}{l}\text { Operating } \\
\text { Income } \\
\text { Growt }\end{array}$ \\
\hline & \multicolumn{6}{|c|}{2014} & $2008-2014$ & $2008-2014$ \\
\hline ELIXIR FOOD DOO, SABAC & 3,654 & 2,987 & 2,580 & 57 & 39 & 125 & $205 \%$ & $302 \%$ \\
\hline SWISSLION DOO, BEOGRAD & 10,226 & 8,024 & 8,991 & 602 & 697 & 873 & $203 \%$ & $183 \%$ \\
\hline GEBI DOO, CANTA VIR & 5,705 & 1,676 & 7,274 & 669 & 147 & 214 & $59 \%$ & $144 \%$ \\
\hline DOO KONZUL NOV SAD & 1,555 & 383 & 5,517 & 100 & 32 & 61 & $49 \%$ & $136 \%$ \\
\hline RAUCH SERBIA & 2,771 & 1,998 & 3,859 & 357 & 284 & 147 & $31 \%$ & $113 \%$ \\
\hline SUNOKO DOO, NOV SAD & 37,353 & 16,149 & 18,312 & 1,418 & 699 & 469 & $769 \%$ & $84 \%$ \\
\hline TE-TO, SENTA & 8,310 & 1,837 & 6,731 & 0 & 0 & 174 & $-14 \%$ & $57 \%$ \\
\hline NECTAR DOO, B. PAL_ANKA & 13,168 & 5,581 & 7,795 & 558 & 180 & 638 & $0 \%$ & $49 \%$ \\
\hline VICTORIAOIL AD, SID & 18,243 & 4,469 & 12,473 & 912 & 0 & 282 & $31 \%$ & $48 \%$ \\
\hline AD IMLFK, BEOGRAD & 27,447 & 10,747 & 22,890 & 3,518 & 2,209 & 768 & $-42 \%$ & $29 \%$ \\
\hline CARNEXDOO, VRBAS & 12,555 & 9,048 & 7,199 & 1,094 & 683 & 950 & $-50 \%$ & $23 \%$ \\
\hline AD F-K.A SECERA, ZABALU & 4,524 & 1,041 & 3,693 & 0 & 0 & 189 & $-22 \%$ & $15 \%$ \\
\hline DIIAMANT AD, ZRENIANIN & 20,741 & 9,691 & 12,768 & 1,432 & 869 & 721 & $-17 \%$ & $12 \%$ \\
\hline SECERANA CRVENKA AD & 8,803 & 2,140 & 5,969 & 0 & 0 & 207 & $-28 \%$ & $-5 \%$ \\
\hline SOIAPROTEN AD, BECEJ & 25,658 & 10,865 & 11,218 & 767 & 252 & 387 & $-3 \%$ & $-42 \%$ \\
\hline Ulkupno & 450,409 & 247,696 & 161,071 & 23,802 & 12,318 & 6,228 & $-8 \%$ & 3446 \\
\hline
\end{tabular}

Source: Serbian Business Registers Agency; Authors' calculations

In analysing business results achieved by food-processing companies, one must bear in mind that their operation is largely affected by factors beyond their control. Main extreme factors are changes in stock exchange prices and fluctuations of foreign exchange rates. Both these factors are characterized by high volatility in the market over the observed period and, according to projections, this trend will continue in the upcoming years. The second factor affecting their operating income is of internal nature and refers to successful business management.

Out of fifteen companies from the food-processing industry under observation, four recognized net loss in 2014 and three of them are sugar-producing companies (TE-TO Senta, ŠećeranaCrvenka, AD Fabrika šećera Žabalj), the fourth being Victoria Oil. First, we tested if the recognized net loss was the consequence of financial and extraordinary expenses or the consequence of company's lack of ability to achieve adequate difference between operating income and operating expense (margin). This information is of vital importance as it provides the answer to the question whether the companies under observation are capable of covering all their operating expenses, which had a share in generating income, according to total expenses method. Out of four net loss-generating companies, three recognized operating loss (all sugar-producing companies) and only one recorded operating profit (Victoria Oil). Having in mind that sugar production requires significant investments in production and equipment modernisation, we examined the trend of the operating profit during the entire observation period. Data 
show that sugar-producing companies recognized operating loss only in 2014. In all previous years, these companies recorded operating profit. Key reasons behind this change lie in unfavourable price of sugar in the international market and high price of gas used as fuel in processing. For this reason, there analysed companies could not cover their operating loss with their operating profit and thus partial profitability indicators are negative for 2014.

The main external problem regarding sugar export is, however, high volatility of its price in European markets along with announced cancellation of EU sugar quotas, with subventions remaining at the same level, which will lead to increased supply. Consequently, this leads to the market instability which in turn reflects on sugarproducing companies' operating results. Sugar prices have a downward trend and thus make it all the more difficult for these companies to fight off the competition from other EU countries which are far better supported by the national subvention system and state-of-the-art technology, so that significant drop in sugar price could force the those less efficient sugar producing companies into loss. Therefore, adequate solutions for sustaining sugar producing industry, which is very significant for exports, must be found within the economic policy as a whole. The perspective of sugar export growth in the future would otherwise be doomed to failure.

Since the companies which recognized operating loss produce stock exchange goods, they do not have any influence on the pricing policy. Their operation is much more influenced by the factor which determines their operating profit which enables them to cover their operating expense, i.e. the issue of reducing operating expenses. For this reason, the first factor we analysed was the structure of operating expenses per year. We may conclude that companies which recognized operating loss had an increased share of depreciation costs in the structure of operating expenses (Victoria Oil, Šid and Sugar Factory Crvenka) and one of the reasons why these companies were unable to achieve positive operating results is the fact that depreciation costs were fixed costs. Due to reduced operating profit and stable trend of these expenses, these 2 companies consequently records negative operating results. Likewise, by examining the share of material costs in the structure of expenses and in relation to operating income we may conclude that the difference (margin) between the cost of material and operating income generated is reduced while the share of these costs increases in the structure of overall expenses (Vukoje, 2009). This situation is only possible due to the fact that the cost of wages is reduced in total structure of expenses in relation to operating income. 
Table 4. The Share of Wages and Amortization in Operating Expenses

\begin{tabular}{|c|c|c|c|c|c|}
\hline \multirow[t]{2}{*}{ COMPANY } & \multicolumn{2}{|c|}{$\begin{array}{c}\text { costs in operating } \\
\text { expenses }\end{array}$} & \multicolumn{2}{|c|}{$\begin{array}{l}\text { The share of amortiz } \\
\text { in operating expenses }\end{array}$} & \multirow{2}{*}{\begin{tabular}{|c|}
$\begin{array}{l}\text { Operating } \\
\text { expenses }\end{array}$ \\
$\mathbf{2 0 1 4 / 2 0 0 9}$ \\
\end{tabular}} \\
\hline & 2014 & 2009 & 2014 & 2009 & \\
\hline SOJAPROTEIN, AD BEČEJ & $5 \%$ & $2 \%$ & $4 \%$ & $1 \%$ & $-30 \%$ \\
\hline VCTORLAOIL AD, ŠID & $3 \%$ & $1 \%$ & $3 \%$ & $2 \%$ & $16 \%$ \\
\hline SUNOKO DOO, NOVI SAD & $5 \%$ & $2 \%$ & $4 \%$ & $1 \%$ & $84 \%$ \\
\hline SWISSLION DOO, BEOGRAD & $8 \%$ & $4 \%$ & $5 \%$ & $6 \%$ & $41 \%$ \\
\hline DUAMANT AD, ZRENJANIN & $8 \%$ & $8 \%$ & $3 \%$ & $3 \%$ & $30 \%$ \\
\hline TE-TO, SENTA & $5 \%$ & $6 \%$ & $3 \%$ & $4 \%$ & $54 \%$ \\
\hline DOO KONZUL, NOVI SAD & $1 \%$ & $2 \%$ & $0 \%$ & $0 \%$ & $198 \%$ \\
\hline RAUCH SERBIA & $7 \%$ & $8 \%$ & $5 \%$ & $7 \%$ & $73 \%$ \\
\hline NECTAR DOO, BAČKA PALANKA & $10 \%$ & $11 \%$ & $4 \%$ & $6 \%$ & $59 \%$ \\
\hline ŠEĆERANA CRVENKA, AD CRVENKA & $7 \%$ & $10 \%$ & $4 \%$ & $3 \%$ & $5 \%$ \\
\hline AD IMIEK, BEOGRAD & $7 \%$ & $11 \%$ & $4 \%$ & $5 \%$ & $33 \%$ \\
\hline GEBI DOO, PO ČANTAVIR & $2 \%$ & $2 \%$ & $2 \%$ & $2 \%$ & $136 \%$ \\
\hline CARNEX DOO, VRBAS & $18 \%$ & $29 \%$ & $6 \%$ & $3 \%$ & $17 \%$ \\
\hline ADFABRIKA ŠEĆERA, ŽABALJ & $8 \%$ & $12 \%$ & $1 \%$ & $3 \%$ & $36 \%$ \\
\hline EIXXR FOOD DOO, ŠABAC & $8 \%$ & $3 \%$ & $4 \%$ & $2 \%$ & $114 \%$ \\
\hline
\end{tabular}

Source: Serbian Business Registers Agency; Authors' calculations

The explanation for negative financial results of Victoria Oil Company can be found in sudden growth of financial expenses. Financial expenses in 2014 increased by 528 million RSD since 2013 and by $38.7 \%$ compared to initial year under observation. It is interesting to examine the movement of financial expenses position. In the period 2009-2013, the company recognized relatively constant financial expenses (cyclic trend characterized by mild growth followed by mild decline) only to increase in 2014 by a record $88 \%$. For this reason, we examine the financial expenses item. In addition to significant growth due to interest expense towards third parties which recorded an increase of 200 million RSD, negative foreign exchange rates and negative trends of foreign currency clauses in transactions with third parties were also observed. This increase is the result of accounting regulations applicable in 2014 which prescribe that all negative foreign exchange differences from the previous periods, which have not been recognized so far, must be recognized in income statements and the balance sheets.

The leverage shows the actions taken as well as the capacity of the company to increase owner's capital by borrowing. The purpose of using leverage is enabling the company's management to borrow at low interest rates and to place and invest such funds in lucrative projects. The trend recorded by the capital multiplier, observed as the ratio of total average assets and total average capital, makes it clear whether the observed companies were in the process of expansion, stagnation or relaxation, as viewed through the prism of utilization of borrowed funds for development purposes. By comparing the value of capital multiplier from 2014 with its value in 2009, we may conclude that two of those 
loss-generating companies (Victoria Oil and TE-TO) significantly lowered the share of borrowings in total financing sourcese (Žabalj, Crvenka) to the level of 77-109\%. Based on obtained data, we cannot claim with certainty that the capital multiplier is the factor which significantly affected the recognition of net operating loss.

The next factor whose effect we examined was fixed-assets turnover rate. This is a financial ratio which shows how many times average engaged fixed-assets are turned over i.e. the number of days in a year is divided with a turnover rate resulting in an average number of days needed to achieve the turnover. The value of this ratio is different for different business activities and even companies in the same industry have different ratios.

Table 5. Turnover Rate for Average Fixed Assets for the Period 2009-2014

\begin{tabular}{|c|c|c|c|c|c|c|c|}
\hline \multirow[t]{2}{*}{ COMPANY } & \multicolumn{7}{|c|}{ Turnover rate (operating income/average as sets) } \\
\hline & 2014 & 2013 & 2012 & 2011 & 2010 & 2009 & $2014 / 2009$ \\
\hline SOJAPROTEIN AD BECEI & 0.46 & 0.52 & 0.78 & 0.71 & 0.78 & 0.82 & $-44 \%$ \\
\hline VICTORIAOIL AD SID & 0.71 & 0.81 & 1.39 & 1.18 & 1.08 & 0.92 & $-23 \%$ \\
\hline SUNOKO DOONOVI SAD & 0.54 & 0.83 & 0.86 & 1.06 & 0.95 & 0.75 & $-27 \%$ \\
\hline SWISSIION DOO BEOGRAD & 0.90 & 1.03 & 0.96 & 0.95 & 0.94 & 1.28 & $-29 \%$ \\
\hline DUAMANT AD ZRENJANIN & 0.58 & 0.60 & 0.86 & 0.77 & 0.83 & 0.65 & $-10 \%$ \\
\hline TE-TO & 0.85 & 1.27 & 1.36 & 1.51 & 1.19 & 0.97 & $-12 \%$ \\
\hline DOO KONZUL NOUI SAD & 4.11 & 4.37 & 4.93 & 4.24 & 2.77 & 2.35 & $74 \%$ \\
\hline RAUCH SERBLA & 1.43 & 1.29 & 1.67 & 1.41 & 1.32 & 1.10 & $30 \%$ \\
\hline NECTAR DOO BACKA PALANKA & 0.59 & 0.58 & 0.61 & 0.68 & 0.67 & 0.65 & $-10 \%$ \\
\hline SECERANA CRVENKA AD CRVENKA & 0.70 & 0.94 & 0.87 & 0.94 & 1.07 & 1.15 & $-39 \%$ \\
\hline AD IMIEK BEOGRAD-PADINSKA SIELA & 0.84 & 0.86 & 1.06 & 1.13 & 1.07 & 1.04 & $-19 \%$ \\
\hline GERI DOO PO CANTAVIR & 1.54 & 1.64 & 1.44 & 1.47 & 1.66 & 1.75 & $-12 \%$ \\
\hline CARAEX DOO VRBAS & 0.59 & 0.60 & 0.83 & 0.78 & 0.83 & 0.92 & $-36 \%$ \\
\hline ADFABRIKA SECERA SAIKASKKA ŻABAL & 0.76 & 0.96 & 0.94 & 1.15 & 1.14 & 0.97 & $-22 \%$ \\
\hline EIIXIR FOOD DOO & 0.66 & 0.37 & 0.69 & 1.06 & 0.91 & 0.94 & $-30 \%$ \\
\hline
\end{tabular}

Source: Serbian Business Registers Agency; Authors' calculations

The turnover rate is precisely the factor which may yield the conclusion on the method used by the management to invest assets in certain forms of business property in order to improve profitability. Higher ratios are expected in more successful companies. By analysing loss-generating companies, we saw that regularity with which companies which recognized loss also experienced significant slow-down in fixed-asset turnover rate in 2014 compared to initial year of the period under observation. What all of these companies share in common is that in 2009, all of them had this ratio above 1 which means that operating income in the course of the year exceeded the average fixedassets' value. In 2014, the turnover rate declined so that this ratio was below one for all analysed loss-generating companies in food-processing industry. It is interesting to note the regularity of this decline as well. All four companies which recorded net loss also experienced the slowing down of fixed-asset turnover ratio between $28 \%$ and $35 \%$ in 2014 when compared to 2009. Detection of this factor is of vital importance because it shows that fixed-asset turnover ratio is a highly important factor for company's operating results. 
By analysing the key elements of Du Pont formula, we may conclude that the decline of profitability and slowing down of turnover rate are factors which determine and promote negative operating results.

\section{Conclusion}

Our investigation confirmed basic hypothesis that Serbian food-processing industry, which relies on processing of domestic agricultural raw materials, is a great chance for increasing export and that it has additional value for the country's economy and significant multiplying effect on other aspects of great importance for the country's future growth. The top 15 exporting companies analysed have very high net export as they use domestic raw material and are not import-dependent. If we have in mind the Serbian import exceeds export and that the group of 100 largest exporters had only $3.5 \%$ share in total export in 2013 and that import of top 100 exporters exceeded their import by $7.4 \%$, the group of 15 largest exporters, with their net export being $70 \%$ of the total export, is superior among net exporters. This means that such companies are extremely important for the country's balance of trade and balance of payment.

Agriculture will not remain the most unused resource only if export based on primary agricultural product is transformed towards developing strong food-processing industry. Food-processing industry has several significant advantages over other industries in respect of export. This industry has a huge potential for growth because countries of similar size have multiple times higher export than Serbia. As opposed to industry which heavily relies on imported components (the example being largest exporters such as Fiat and Zelezara Smederevo), food-processing industry has a relative low share of imported components which makes the food-processing companies, in addition to being large net exporters, also the top quality part of the Serbia's industry as it contributes the most to its added value. For illustration purposes, the contribution of Železara Smederevo may be high from the standpoint of increasing gross domestic product but its net export and added-value contribution would be relatively low due to high dependency on import. It is justifiable to question the effects which could have been achieved if 100 million euros of subventions a year invested in its operation had been invested instead into the growth of food-processing industry in order to change the export structure and achieve lower share of primary agricultural products in export, characterised by low profit margins and low added-value, and increase the export of companies which process these agricultural products.

Business performances of analysed exporters are not satisfactory and export competitiveness of such companies needs to be enhanced. Global market is characterised by high volatility of prices for stock exchange goods which are also the basic raw material used by processing industry. The competition is stronger and consolidation is occurring on the large scale. As higher market turbulences can be expected in the future, it is unclear whether currently relatively successful processing companies can maintain their position in the market or if they should consider forming strategic partnerships with large companies. The sugar-producing companies will face the greatest challenges 
whereas fruit processing has the best long-term potential for increasing export. In the face of such upcoming changes, it is most important, however, to improve current business environment in Serbia and to ensure adequate participation of processed agricultural products in export within the implementation of the strategy for strengthening export as this would in effect imply the use one of Serbia's rare comparative advantages.

\section{References}

1. European Commission (2014): Progress Report for Serbia. Brussels.

2. European Commission, (2010): EUROPE 2020 - A strategy for smart, sustainable and inclusive growth. Brussels.

3. Food and Agriculture Organization of the United Nations (2015): The State of Agricultural Commodity Markets 2015/2016. Agriculture. Rome.

4. Hausmann, R., Hwang, J., Rodrik, D. (2006): What You Export Matters. Working Paper. Center for International Development, Harvard University.

5. Hesse, H. (2008): Export Diversification and Economic Growth. Working paper 21, The World Bank On behalf of the Commission on Growth and Development, Washington.

6. Hidalgo, C., Klinger, B., Barbasi, A., Hausmann, R. (2007): The product space condicions the development of nations, Science, pp. 317-329.

7. Jeremić, Z., Milojevic, M., Terzć, I. (2015): Business performance of the largest exporters in Serbia during the period 2008-2014. Ekonomika preduzeća, Vol. 63, No. 5-6, pp. 293-305, Beograd.

8. Jeremić, Z., Milojevic, M. (2015): The most successful exporters and importers in period 2008-2014, The Economy and Finance Board 2015, Business Info Group, Kopaonik business forum, pp. 6-37, Beograd.

9. Jolović, A., Njegovan, Z., Čavlin, M. (2014): Finansiranje poljoprivrede u Srbiji - stanje i perspective. Ekonomika poljoprivrede, Vol. 61, No. 1, pp. 127-137, Beograd.

10. Ljunović, I., Viduka, B., Cvijanović, J. (2015): Acces to finance for organic producers in Serbia: Demand side. Ekonomika poljoprivrede, Vol. 62, No. 4, pp. 989-1002, Beograd.

11. Miletić V., Milosavljević D., Kostić B. (2012): Institutional Investment Policy Frameworks for the Agriculture of the Republic of Serbia. Ekonomika poljoprivrede. Vol. 59, No. 3, pp. 363-377, Beograd.

12. Milojević, M., Terzić I. (2015): Liquidity of large companies in the Republic of Serbia. Ekonomika, Vol. 61, No. 3, pp. 173-183, Niš.

13. Pejanović, R. (2009): Razvojni problemi poljoprivrede Republike Srbije. Agroekonomika. Poljoprivredni fakultet, No. 41-42, pp. 5-24, Novi Sad.

14. Pejanović, R., Cvijanović, D., Njegovan Z., Tica, N., Živković, D. (2009): Problemi poljoprivrede Republike Srbije i mere za prevazilaženje krize. Ekonomika 
poljoprivrede, Vol. 56, No. 2, pp. 221-230, Beograd.

15. Simeunović, T., Milošević, V. (2013): Važnost analize finansijskih izveštaja poljoprivrednih preduzeća sa osvrtom na kvalitet. Poljoprivredni fakultet, No. 5960, pp. 79-84. Novi Sad.

16. Stevanović, S., Milanović M. and Milačić S. (2013): Problems of the deindustrialization of the Serbian Economy. Ekonomika poljoprivrede, Vol. 60, No. 3, pp. 465-479, Beograd.

17. European Commission (2015): Strategy for development of small and mid-sized companies, entrepreneurship and competitiveness in the period 2015-2020., SBA Fact Sheet, 1-15, Brussels.

18. Vukoje, V. (2009): Osnovne determinante računovodstva troškova poljoprivrednih preduzeća. Agroekonomika. Poljoprivredni fakultet, No. 41-42, pp. 95-106, Novi Sad.

19. World Bank (2012): Republic of Serbia, The Road to Prosperity: Productivity and Exports, Country Economic Memorandum, p. 22-43, Washington.

20. World Bank (2014): Rebalancing Serbia's Economy - Improving Competitiveness, Strengthening the Private Sector and Creating Jobs. Working paper, Washington. 


\title{
POSLOVNE PERFORMANSE 15 NAJVEĆIH IZVOZNIKA IZ PREHRAMBENO-PRERAĐIVAČKE INDUSTRIJEU PERIODU 2008- 2014. GODINA
}

\author{
Zoran Jeremić, ${ }^{6}$ Marko Milojević ${ }^{7}$, Ivica Terzic ${ }^{8}$ \\ Sažetak
}

U strukturiizvoza poljoprivrede Srbije dominiraju proizvodi primarne poljoprivredne proizvodnje, dok proizvodi višeg stepena prerade čine tek oko petine ostvarenog izvoza. Tako nizak procenat izvoza proizvoda više faze prerade ujedno je i šansa za veliko povećanje izvoza i promenu njegove strukture ka proizvodima veće dodajne vrednosti. Da bi se to dogodilo, potrebno je razviti prerađivačku industriju zasnovanu napreradi domaćih poljoprivrednih proizvoda. U radu se analiziraju poslovne performance 15 najvećih izvoznika iz sektora prerađivačko prehrambene industrije s ciljem da se sagleda njihova izvozna konkurentnost. Zaključakrada je da su ova preduzeća veliki neto izvoznici gde postoji visoka dodata vrednost za ekonomiju zemlje. Poslovne performance analiziranih izvoznika nisu, međutim, zadovoljavajuće, pa je neophodno da unaprede svoju izvoznu konkurentnost. Predviđa se da će u narednom periodu pred najvećim izazovima biti poslovanje šećerana, a da prerada voća ima najveći dugoročni potencijal za rast izvoza.

Ključne reči: prehrambena industrija, izvoz, konkurentnost

6 Profesor, dr Zoran B. Jeremić, Univerzitet Singidunum, Poslovni fakultet u Beogradu, Danijelova ulica br. 32, 11000 Beograd, Srbija, Telefon: +381 11 3020035, E-mail: zjeremic@singidunum.ac.rs

7 Docent, dr Marko Milojević, Univerzitet Singidunum, Poslovni fakultet u Beogradu, Danijelova ulica br. 32, 11000 Beograd, Srbija, Telefon: +381 11 3020035, E-mail: mmilojevic@singidunum.ac.rs

8 Docent, dr Ivica Terzić, Univerzitet Singidunum, Poslovni fakultet u Beogradu, Danijelova ulica br. 32, 11000 Beograd, Srbija, Telefon:+381 11 3020035, E-mail: iterzic@singidunum.ac.rs

EP 2016 (63) 3 (943-957) 